\title{
ORAL TRANSIT TIME: A CRITICAL REVIEW OF THE LITERATURE
}

\author{
Tempo de trânsito oral: revisão crítica da literatura
}

Thais Jacóe SOARES, Danielle Pedroni MORAES, Gisele Chagas de MEDEIROS,

Fernanda Chiarion SASSI, Bruno ZILBERSTEIN, Claudia Regina Furquim de ANDRADE

From the Instituto Central do Hospital das Clínicas, Faculdade de Medicina, Universidade de São Paulo (Central Institute of the Hospital das Clinicas, School of Medicine, São Paulo University), São Paulo, $\mathrm{SP}$, Brazil.

HEADINGS - Deglutition. Deglutition disorders. Evaluation. Speech. Language and hearing sciences. Nutritional status.
ABSTRACT - Introduction: Oral transit time is one of the parameters observed during the clinical assessment of the swallowing function. The importance of this parameter is due to its impact on the total duration of a meal, whose consequence can be an unfavorable nutritional prognostic. Objective: To document scientific papers that measure oral transit time in healthy subjects. Method: The review followed the steps proposed by the Cochrane Handbook. The search was done via the PubMed database through the use of descriptors related to the oral phase of swallowing, as well as to types of food consistency. Results: The articles on the theme had different definitions for oral transit time, as well as heterogeneity of tested volumes, age and gender of the participants. The times found varied from $0.35 \mathrm{~s}$ to $1.54 \mathrm{~s}$ for liquids, from 0.39 $\mathrm{s}$ to $1.05 \mathrm{~s}$ for pasty foods and from $1 \mathrm{~s}$ to $12.8 \mathrm{~s}$ for solid foods. Also, regardless of volume or consistency, oral transit time in elderly people is significantly longer than in adults. Conclusion: There's no consensus in the literature about oral transit time in healthy subjects. However, this parameter should be valued during the assessment of the swallowing function due to its negative impact on the dynamics of swallowing, which can cause high energy expenditure during feeding.

\section{Correspondence:}

Claudia Regina Furquim de Andrade

E-mail: clauan@usp.br

Financial source: none

Conflicts of interest: none

Received for publication: 21/08/2014 Accepted for publication: 09/12/2014

DESCRTORES - Deglutição. Transtornos de deglutição. Avaliação. Fonoaudiologia. Estado nutricional.
RESUMO - Introdução: O tempo de trânsito oral é um dos parâmetros observados na avaliação clínica da deglutição. A importância se deve ao seu impacto na duração total da refeição, o que pode ter como consequência prognóstico nutricional desfavorável. Objetivo. Documentar os textos científicos internacionais que abordem o tempo de trânsito oral em sujeitos saudáveis. Método: Estudo de revisão crítica que segue os preceitos do Cochrane Handbook. Os artigos foram selecionados por meio da base de dados PubMed, com utilização de descritores relacionados à fase oral da deglutição e aos tipos de consistência alimentar. Resultado: Os trabalhos analisados divergiram quanto à definição de tempo de trânsito oral, bem como quanto aos volumes testados e às idades e gêneros dos sujeitos avaliados. Os tempos encontrados variaram de $0,35 \mathrm{~s}$ a $1,54 \mathrm{~s}$ para líquido, de $0,39 \mathrm{~s}$ a $1,05 \mathrm{~s}$ para a consistência pastosa e de $1 \mathrm{~s}$ a $12,8 \mathrm{~s}$ para a consistência sólida. Foi observado também que o tempo de trânsito oral é significativamente aumentado em idosos, em relação a adultos, independente de volume e consistência alimentar. Conclusão: Não há consenso na literatura quanto ao tempo de trânsito oral na população saudável. Ainda assim, entende-se que este parâmetro deva ser valorizado durante a avaliação da disfagia, uma vez que possui impacto negativo na dinâmica da deglutição, o que acarreta desgaste energético ocasionado pela alimentação.

\section{INTRODUCTION}

T he treatment of in bed dysphagia patient must be multidisciplinary to minimize the risk of complications ${ }^{1}$. As a member of the multidisciplinary team in the treatment of dysphagia, the speech therapist aims to restore the efficiency of oral feeding, reducing the risk of aspiration and maintaining nutrition and hydratation levels $\mathrm{s}^{3,22}$.

Dysphagia evaluation comprises the analysis of pharyngeal and high part of digestive system structures and oral functions, and can be both clinical and instrumental. Clinical evaluation includes: anatomical and postural assessment of the structures of the face and neck; physiology observation of the muscles and other structures used in the function of swallowing, except those contained in the pharynx and larynx, whose visualization requires instruments; functional analysis of swallowing; estimate of the adequacy of the protection of the lower airways and coordination between breathing and swallowing; and, finally, control evaluation of saliva ${ }^{2}$. One of the clinical parameters for dysphagia assessment is the oral transit time (TTO). The literature defines this term in different ways. Can be understood as the gap between the complete capture of the bolus and the reflex firing of swallowing, as the interval between the onset of the bolus propulsion until its initial portion exceeds the tongue baseline ${ }^{16,19}$. The importance of valuing this parameter is due to two different factors. The first is the significant relationship between increased TTO and presence of dysphagia $a^{8,12,14}$. Second, the impact of TTO relates the duration of the meal, which results in unfavorable nutritional prognosis 13,23 .

The purpose of this systematic review was to document the scientific texts that address the extent TTO in normal people. 
METHOD

This is a qualitative study of the literature. For the establishment of research strategies were followed the precepts of the Cochrane Handbook ${ }^{27}$ involving: question formulation, location, selection and critical evaluation of the studies.

The articles analyzed were selected through the PubMed database. The headings have been associated with Boolean operators, allowing the inclusion of synonymous keywords, thus increasing the scope of search. The searches were carried out: "(oral phase AND (OR deglutition swallowing)) consistency AND", "(oral phase AND (OR deglutition swallowing)) AND liquid", "(oral phase AND (OR deglutition swallowing)) AND (OR puree OR pasty paste)","(oral phase AND (OR deglutition swallowing)) AND (semisolid semi-solid OR)","(oral phase AND (OR deglutition swallowing)) AND solid "," oral transit time consistency AND" "oral transit time AND liquid", "oral AND transit time (pasty puree OR paste)", "oral AND transit time (semisolid semi-solid OR)" and "oral transit time AND solid".

Filters were applied which limited the results to research involving human from the age of 19, written in the languages English and Spanish and published between 2003 and 2013. From the search of the texts in the database, were excluded articles echoed by overlapping keywords and papers that were not related to the topic.

After analyzing the articles, the following exclusion criteria were applied: articles that did not mention the measure of TTO; those whose control group was not composed of healthy subjects; and research conducted only with individuals diagnosed with an illness.

All stages of the study were conducted independently by researchers. When there was disagreement were only included those texts on which the final opinion was unanimous. The process of selecting the texts initially included 90 articles. Of these, 81 were excluded, resulting total of nine articles. After, thorough reading was performed the identification of the type of study, number, gender and age of the participants, purpose, evaluation instrumental, definition of TTO contemplated, consistency(s) food(s) used, volume of food offered, results obtained, and finally, the paper conclusion. Thus, nine paragraphs will be presented, relating to each item included in this study, followed by explanations of them.

RESULT

Cassiani et $\mathrm{al}^{7}$ evaluated the swallowing of 30 healthy subjects, 18 men and 12 women, aged between 29 and 77 years. The objective was to investigate the relationship between the duration of the oral and pharyngeal phases of swallowing. The instrumental evaluation method chosen was the videofluoroscopy. The article defines TTO as the time between the incision and the passage of the last portion of the bolus by the jaws. The subjects were evaluated offering duplicate of 5 and $10 \mathrm{ml}$ of liquid barium, and 5 and $10 \mathrm{ml}$ of pasty barium. There was no significant difference between the TTO for the two consistencies. Nor was found TTO difference between the two different volumes for each offered consistency. The TTO for both liquid volume was $0.42 \mathrm{~s}$, while the TTO for the two pasty volume was $0.41 \mathrm{~s}$. The study found a correlation between TTO and the duration of the pharyngeal clearance during swallowing of pasty food bolus.

Saitoh et $\mathrm{al}^{17}$ evaluated 15 healthy young adults, among these nine men and six women with a mean age of 30 years (standard deviation of \pm 5.2 ). The objectives of the study were to examine the hypothesis that food transportation to the pharynx and clumping of the bolus in the region are related to the function of mastication, as well as to review the food transportation mechanism into the pharynx results from the tongue or the gravity action. The swallowing of the population was assessed by video fluoroscopy. The article defines TTO as the time between the incision of the alimentary bolus and passage of the initial portion thereof in the posterior nasal spine. The subjects ingested $10 \mathrm{ml}$ of liquid barium, $8 \mathrm{~g}$ barium biscuit with buttery and $8 \mathrm{~g}$ of barium with ground beef stew with potatoes. The TTO found for liquid barium was $1.54 \mathrm{~s}$; for barium mixed to solid foods was $6.93 \mathrm{~s}$ and $12.8 \mathrm{~s}$ to meat stew to the biscuit. The study found that chewing and the consistency of bolus altered the relationship between the food transportation and the beginning of swallowing. It also found that the food transport to the hypopharynx was highly dependent on gravity, while solid food shipping to valleculae is active, depending primarily on the contact between the tongue and the palate.

Silva et $\mathrm{al}^{20}$ in case-control study compared the swallowing of 26 patients after ischemic stroke, aged 26 to 83 years, 15 healthy adults aged 27 to 86 years. The article does not mention the gender of the population, saying only the compatibility existence of this aspect between the two groups. The aim was to study swallowing after stroke patients through clinical and scintigraphic evaluation. The TTO was defined as the time interval required for the passage of the bolus through the mouth, i.e. until the posterior portion of the oral cavity exit. The subjects ingested $5 \mathrm{ml}$ of liquid and $5 \mathrm{ml}$ of pasty. Both consistencies were prepared with water and juice. To obtain the pasty consistency, was added $4.5 \mathrm{~g}$ food thickener in 50 $\mathrm{ml}$ of the prepared water and/or juice. The TTO found with the liquid was $0.97 \mathrm{~s}$ for the control group and $0.98 \mathrm{~s}$ for the study group. The TTO for the pasty food was $0.76 \mathrm{~s}$ for the control group and $1.10 \mathrm{~s}$ for the study group. The difference between the times was not significant. The study concluded that the association between clinical and instrumental assessment of swallowing after stroke patients allowed to obtain a correct diagnosis, as well as the efficiency of the rehabilitation process

Silva et al ${ }^{21}$ similarly in another case-control study compared the swallowing of 26 patients after ischemic stroke, all men aged between 26 and 83 years, to 15 healthy volunteers, seven men and eight women, aged between 27 and 86 years. The objective was to verify the hypothesis that stroke affects the esophageal transit time. The test chosen for the evaluation was instrumental scintigraphy. The TTO was defined as the time required for the passage of the bolus through the mouth to the beginning of the swallowing reflex. The subjects ingested $5 \mathrm{ml}$ of liquid and $5 \mathrm{ml}$ of pasty. Both consistencies were prepared with water and juice powder. To obtain the pasty consistency, was added $4.5 \mathrm{~g}$ food thickener to $50 \mathrm{ml}$ of the prepared water and juice powder. The TTO found with the liquid was $0.97 \mathrm{~s}$ for the control group and $0.98 \mathrm{~s}$ for the study group. The TTO for the pasty food was $0.76 \mathrm{~s}$ for the control group and 1.10 $\mathrm{s}$ for the study group. The difference between the times was not significant. The study concluded that patients who have had strokes, liquid oral feeding can have alterations in the esophageal transit.

Santos et $\mathrm{al}^{18}$ in case-control study compared 17 patients with Chagas' disease and 15 healthy volunteers. Those with Chagas, eight men and nine women, were aged between 31 and 67 years. Healthy subjects, eight men and seven women, were aged between 35 and 69 years. The objective was to verify the hypothesis that there are changes in TTO and pharyngeal transit time in Chagas disease. The survey was conducted by means of videofluoroscopy. The TTO has been defined as that between the time in which the tip of the tongue touches the palate, after preparation and bolus centralization, and the time when the final portion of it exceeds the jaws. Participants received duplicate offers of 5 and $10 \mathrm{ml}$ of liquid barium, and 5 and $10 \mathrm{ml}$ of pasty barium. The TTO values found for healthy volunteers were $0.57 \mathrm{~s}$ to $5 \mathrm{ml}$ of liquid barium, $0.47 \mathrm{~s}$ to $10 \mathrm{ml}$ of liquid barium, $0.72 \mathrm{~s}$ to $5 \mathrm{ml}$ pasty barium and $0.54 \mathrm{~s}$ to $10 \mathrm{ml}$ pasty barium. The TTO values found for patients with Chagas disease were $0.62 \mathrm{~s}$ to $5 \mathrm{ml}$ of liquid barium, $0.62 \mathrm{~s}$ to $10 \mathrm{ml}$ of 
liquid barium, $0.59 \mathrm{~s}$ to $5 \mathrm{ml}$ pasty barium and $0.59 \mathrm{~s}$ to $10 \mathrm{ml}$ of barium paste. The only significant difference between the times of the two groups was achieved with $10 \mathrm{ml}$ of liquid barium. The study concluded that the pharyngeal transit time is longer in people with Chagas disease compared to healthy people.

Still on Chagas disease, Gomes et $\mathrm{al}^{10}$ in another casecontrol study examined the swallowing of 20 patients with the disease, 14 women and six men aged between 27 and 81 years, compared to 21 healthy subjects, two men and 19 women, aged between 22 and 75 years. Both groups were subdivided according to age group. Patients with Chagas were subdivided into a group of 10 adults between 27 and 57 years and another 10 adults between 58 and 81 years. The control group was subdivided into a group of 11 subjects between 27 and 56 years and another of 10 subjects between 57 and 65 years old. The objective was to evaluate the oral and pharyngeal stages of swallowing soft foods in patients with Chagas. The test used was scintigraphy. The TTO was defined as the interval between the beginning and the end of the oral emptying. The subjects ingested $10 \mathrm{ml}$ of pasty food prepared by adding $4.5 \mathrm{~g}$ food thickener to $50 \mathrm{ml}$ of water. The TTO in $10 \mathrm{ml}$ pasty food in young people was $0.58 \mathrm{~s}$ in the control group and $0.56 \mathrm{~s}$ in the study group. The TTO of $10 \mathrm{ml}$ pasty food in older people was $0.83 \mathrm{~s}$ for the control group and $0.71 \mathrm{~s}$ for the study group. There was no significant difference between the TTO groups. The study concluded that patients with Chagas disease may be at greater amount of residue in the oral cavity as well as longer duration of throat clearing.

Yoshikawa et $\mathrm{al}^{28}$ in case-control study compared the swallowing of 19 healthy elderly toothed without chewing complaints, aged 80 to 87 years, 12 men and seven women, the swallowing of 14 healthy adults, nine men and five women, aged between 24 and 32 years. The objective was to clarify the primary influence of aging on swallowing on toothed and healthy elderly with more than 80 years, with more than 20 teeth. The test used was the videofluoroscopy. In this study, TTO was defined as the interval between the onset of tongue movement at the beginning of voluntary and oral phase of swallowing the time when the bolus reaches the intersection point between the jaw and the base of the tongue. Participants received three offers of $10 \mathrm{ml}$ of liquid barium. The TTO to $10 \mathrm{ml}$ of liquid barium found in the adult group was $0.74 \mathrm{~s}$. The TTO found to $10 \mathrm{ml}$ of liquid barium in the elderly group was significantly higher, $1.05 \mathrm{~s}$. The study found that that there is damage to the physiological function of swallowing even in healthy and dentate people.

Dantas et $\mathrm{al}^{9}$ in a clinical study evaluated the swallowing of 30 healthy volunteers, including 18 men aged between 33 and 77 years and 12 women aged between 29 and 72 years. The aim was to compare the swallowing of men and women asymptomatic through videofluoroscopy. In this article, the TTO was defined as the interval between the moment when the tip of the tongue touches the palate, after preparation and centering the bolus, and the time at which the final portion of the bolus exceeds the jaws. Participants received duplicate offers of 5 and $10 \mathrm{ml}$ of liquid barium and 5 and $10 \mathrm{ml}$ of pasty barium. To obtain the pasty consistency, was added $4.5 \mathrm{~g}$ food thickener to $50 \mathrm{ml}$ of liquid barium. The TTO to $5 \mathrm{ml}$ of liquid barium was $0.41 \mathrm{~s}$ for men and $0.59 \mathrm{~s}$ for women. The TTO to 10 $\mathrm{ml}$ of liquid barium was $0.36 \mathrm{~s}$ for men and $0.35 \mathrm{~s}$ for women. The TTO to $5 \mathrm{ml}$ pasty barium was $0.39 \mathrm{~s}$ for men and $0.59 \mathrm{~s}$ for women. The TTO to $10 \mathrm{ml}$ pasty barium was $0.35 \mathrm{~s}$ for men and $0.38 \mathrm{~s}$ for women. There was a significant difference between the TTO of $5 \mathrm{ml}$ of liquid and pasty for men and women. The study concluded that there is a difference between men and women swallowing, since women oropharyngeal transit have increased time relative to males for a $5 \mathrm{ml}$ bolus of doughy food.

Finally, Baulieu et a ${ }^{6}$ in clinical study examined the swallowing of 30 healthy subjects, aged between 21 and 77 years. The gender of the population was not specified. The goal was to select a solid bolus suitable for scintigraphic examination of the esophagus.
The TTO was defined as the time required for the passage of the bolus through the mouth to the exit from the oral cavity. The subjects ingested 1 to $3 \mathrm{ml}$ of scrambled egg (whole egg and egg white only). The TTO found for $1 \mathrm{ml}$ and $3 \mathrm{ml}$ of scrambled egg done only with white were 1.7 and 2.7 seconds, respectively. The TTO found to $1 \mathrm{ml}$ and $3 \mathrm{ml}$ of scrambled eggs made with whole egg were 1.0 and $1.6 \mathrm{~s}$, respectively. The study found a bolus of $3 \mathrm{ml}$ of scrambled egg (whole egg) radiolabeled appears to be best suited for the examination of the esophageal transit, and its use can increase the potential of scintigraphic evaluation of esophageal disorders.

The studies presented show that the TTO is considered an important parameter in the evaluation of swallowing because it is objective measure easily obtainable, both during clinical and objective evaluation ${ }^{13}$. However, the analysis of these studies shows that there is disagreement to TTO definitions.

Cassini et al. ${ }^{7}$, Saitoh et al. ${ }^{17}$, Silva et al. ${ }^{20}$, Silva et al. ${ }^{21}$, Yoshikawa et $\mathrm{al}^{28}$. and Baulieu et al. ${ }^{6}$ describe the TTO as the time of the oral preparatory phase of swallowing added to the time of the oral procedure in itself. The oral preparatory stage is defined as a food preparation for transportation, which includes incision, chewing and the centralization of bolus in oral cavity. The oral stage itself is defined as one in which the bolus is driven to oropharin $x^{3}$. These authors agree that the TTO begins with the introduction of food or incision in the oral cavity. However, different descriptions are given to the range end point. Five of the articles define this point as the passage of bolus for some anatomical structure, such as jaws, posterior nasal spine, posterior boundary of the oral cavity and crossing point between the jaw and base of the tongue. However, it is known that the response of swallowing can be triggered not only by saliva or bolus contact to tonsil fauces, but also different locations of the larynx, including the valleculae, epiglottis and piriform sinuses ${ }^{3}$. Only Silva et al. ${ }^{21}$ consider this variation, since the TTO define the end point of functional form, i.e., as the beginning of the swallowing reflex.

The TTO found in articles that use this definition was: 0.42 $\mathrm{s}$ and $0.97 \mathrm{~s}$ ( $5 \mathrm{ml}$ liquid in indiscriminate groups of adults and seniors); $0.42 \mathrm{~s}$ and $1.54 \mathrm{~s}$ (for $10 \mathrm{ml}$ liquid in adults and elderly groups); $0.74 \mathrm{~s}$ (for $10 \mathrm{ml}$ of liquid in a group of adults); 1.05 $\mathrm{s}$ (for $10 \mathrm{ml}$ of liquid in a group of elderly); $0.41 \mathrm{~s}$ and $0.76 \mathrm{~s}$ ( $5 \mathrm{ml}$ pasty in adults and elderly groups); $0.41 \mathrm{~s} \mathrm{(10} \mathrm{ml} \mathrm{pasty}$ in adults and elderly groups); $1 \mathrm{~s}$ and $1.7 \mathrm{~s}$ (for $1 \mathrm{ml}$ of solids in adults and elderly groups); $1.6 \mathrm{~s}$ and $2.7 \mathrm{~s} \mathrm{(3} \mathrm{ml} \mathrm{solids} \mathrm{in}$ groups of adults and seniors) and $12.8 \mathrm{~s}$ ( $8 \mathrm{~g}$ solids in adults and elderly groups).

The other groups of authors, Santos et al. ${ }^{18}$, Dantas et al. ${ }^{9}$ and Gomes et al. ${ }^{10}$ describe the TTO as the time of the oral procedure itself. The authors mentioned that the TTO starts after preparation and centralization of bolus. All of them use anatomical markers in their definitions, stating the TTO as the interval necessary to propel the bolus for the oropharynx, ie between the contact of tip of the tongue to the hard palate and the passage of the bolus through tonsil fauces, or between beginning and the end of the emptying of the oral cavity.

The TTO found in articles that use this other definition was: $0.57 \mathrm{~s}$ ( $5 \mathrm{ml}$ liquid in adults and elderly of both genders); $0.41 \mathrm{~s}(5 \mathrm{ml}$ liquid in male adults and the elderly); $0.59 \mathrm{~s}(5 \mathrm{ml}$ liquid in adult and elderly females); $0.47 \mathrm{~s}$ (for $10 \mathrm{ml}$ liquid in adults and elderly of both genders); $0.58 \mathrm{~s}$ (for $10 \mathrm{ml}$ liquid in adults of both genders); $0.83 \mathrm{~s}$ (for $10 \mathrm{ml}$ liquid in the elderly of both genders); $0.36 \mathrm{~s}$ (for $10 \mathrm{ml}$ liquid in male adults and the elderly); $0.35 \mathrm{~s}$ (10 ml liquid in adult and elderly females); $0.39 \mathrm{~s}(5 \mathrm{ml}$ pasty in male adults and the elderly); $0.59 \mathrm{~s}(5 \mathrm{ml}$ pasty in adult and elderly females); $0.71 \mathrm{~s}(10 \mathrm{ml}$ pasty in the elderly of both genders); $0.56 \mathrm{~s} \mathrm{(10} \mathrm{ml} \mathrm{pasty} \mathrm{in} \mathrm{adults} \mathrm{of} \mathrm{both}$ genders); $0.35 \mathrm{~s}$ (10 ml pasty in adults and male seniors) and $0.38 \mathrm{~s}(10 \mathrm{ml}$ pasty in adult and elderly females).

Another aspect to review is the fact that none of the articles analyzed in this study provides objective measures for 
consistencies. Information about the exact consistency of the bolus offered during the evaluation are of great value, since this characteristic impacts in deglutition ${ }^{11,26}$. The more consistent and viscous the food is, the higher also the TTO and hence the total deglutition time ${ }^{11,26}$. The objective measure recommended by videofluoroscopic valuation models, provided by the American Speech-Language-Hearing Association-ASHA, is the viscosity expressed in centipoise $(\mathrm{CP})^{4,5,24}$.

On the difference between the TTO of men and women, Dantas et al. ${ }^{9}$ found significant differences between the genders to $5 \mathrm{ml}$ of fluid and $5 \mathrm{ml}$ of pasty food. The literature, which includes the study itself, proposes the hypothesis that these differences are due to anatomical and physiological variations between men and women ${ }^{9}$. However, other articles on the subject demonstrate the absence of distinct swallowing patterns between genders ${ }^{15}$

Another variable compared in two of the articles was age. In one of these studies, Yoshikawa et al. ${ }^{28}$ found significant differences between the TTO of healthy adults (24-32 years) and healthy elderly (80-87 years) for the tested consistency. This same study concluded that there is prejudice to the physiological swallowing function in healthy elderly. The other study of Gomez et al., dedicated to identify swallowing patterns of two groups and reported no significant difference between them. They compared two groups of healthy people, the first one with individuals between 27 and 56 years of age and the second of elderly people aged 57 and 65 years of age. The maximum difference in age between the two groups was small, 56 to $65 \mathrm{y}$, which may explain the findings obtained.

We need to consider the difference between the swallowing patterns of healthy adults and the elderly so as not to incur errors during evaluation, since the physiological aging of swallowing, is recognized and common ${ }^{25}$. The aging effects on the physiology of swallowing include the reduction of muscle mass and elasticity of the tissue, which causes loss of strength and mobility of structures ${ }^{25}$. The impacts of these changes include increased TTO ${ }^{25}$

Thus, the TTO found, taking into account all analyzed items, will vary from $0.35 \mathrm{~s}$ to $1.54 \mathrm{~s}$ for liquid, from $1.05 \mathrm{~s}$ to $0.39 \mathrm{~s}$ in pasty foods and from $1 \mathrm{~s}$ to $12.8 \mathrm{~s}$ for solid consistency.

The importance of having accurate data on the TTO is because it is related to the nutritional status of patient with dysphagia. Although increasing in TTO is not a predictor of aspiration, there is negative impact on patients nutritional status ${ }^{12,25}$.

\section{CONCLUSION}

There is no consensus in the literature regard to TTO in the healthy population. However, regardless of the definition adopted, the interval increase will cause increase of the total time of the meal, that has adverse effects on the nutritional status due to energy expenditure caused by the delay. Therefore, it is understood that this parameter should be valued in swallowing evaluation

\section{REFERÊNCIAS}

1. Abdulmassih EMS, Macedo Filho ED, Santos RS, Jurkiewicz AL. Evolução de pacientes com disfagia orofaríngea em ambiente hospitalar. Arq Int Otorrinolaringol. 2009;13(1):56-62.

2. American Speech-Language-Hearing Association [Internet]. SpeechLanguage Pathology Medical Review Guidelines. [cited 2013 October] Available from: http://www.asha.org/uploadedFiles/SLP-MedicalReview-Guidelines.pdf

3. AmericanSpeech-Language-Hearing Association [Internet]. Treatment Efficacy Summary: Swallowing Disorders (Dysphagia in Adults). [cited 2013 December];Available from:http://www.asha.org/uploadedFiles/ public/TESDysphagiainAdults.pdf
4. American Speech-Language-Hearing Association [Internet]. Videofluoroscopic Swallowing Exam Template for Infants and Children Consuming Purees Through Table Foods. [cited 2013 November]; Available from: http://www.asha.org/uploadedFiles/ VFSS-Exam-Template-Infants-Consuming-Purees.pdf

5. American Speech-Language-Hearing Association [Internet]. Videofluoroscopic Swallowing Exam Template for Infants with Liquid Intake Only. [cited 2013 November]; Available from: http:// www.asha.org/uploadedFiles/VFSS-Exam-Template-Infants-LiquidIntake-Only.pdf

6. Baulieu F, Boiron M, Bertrand P, Guilloteau D, Baulieu JL, Metman EH. Evaluation of a Solid Bolus Suitable for Esophageal Scintigraphy. Dysphagia. 2007:22:281-289.

7. Cassiani RA, Santos CM, Parreira LC, Dantas RO. The relationship between the oral and pharyngeal phases of swallowing. Clinics. 2011;66(8):1385-1388.

8. Daniels ST, Schroeder MF, McClain M, Corey DM, Rosenbek JC, Foundas AL. Dysphagia in stroke: development of a standard method to examine swallowing recovery. JRRD. 2006;43(3):347-356.

9. Dantas RO, Cassiani RA, Santos CM, Gonzaga GC, Alves LMT, Mazin SC. Effect of Gender on Swallow Event Duration Assessed by Videofluoroscopy. Dysphagia. 2009;24:280-284.

10. Gomes FR, Secaf M, Kubo TTA, Dantas RO. Oral and Pharyngeal Transit of a Paste Bolus in Chagas' Disease. Dysphagia. 2008;23:82-87.

11. Lee J, Sejdic E, Steele CM, Chau T. Effects of liquid stimuli on dual-axis swallowing accelerometry signals in a healthy population. Biomed Eng Online. 2010;9:7

12. Li B, Zhang T, Sun X, Xu J, Jiang G. Quantitative videofluoroscopic analysis of penetration-aspiration in post-stroke patients. Neurol India. 2010;58(1):42-47.

13. Lustre NS, Freire TRB, Silvério CC. Temporal measurements of oral transit time in children with cerebral palsy of different levels motors and the relationship with the severity of dysphagia. Audiol Commun Res. 2013;18(3).

14. Mann, G. Hankey GJ, Cameron D. Swallowing function after stroke: prognosis and prognostic factors at 6 months. Stroke. 1999;30:744748.

15. Molfenter SM, Steele CM. Variations in temporal measures of swallowing: sex and volume effects. Dysphagia. 2013;28(2):226-233.

16. Padovani AR, Moraes DP, Mangili LD, Andrade CRF. Protocolo fonoaudiológico de avaliação do risco para disfagia (PARD). Rev Soc Bras Fonoaudiol. 2007;12(3):199-205.

17. Saitoh E, Shibata S, Matsuo K, Baba M, Fujii W, Palmer JB. Chewing and Food Consistency: Effects on Bolus Transport and Swallow Initiation. Dysphagia. 2007;22:100-107.

18. Santos CM, Cassiani RA, Dantas RO. Videofluoroscopic Evaluation of Swallowing in Chagas' Disease. Dysphagia. 2011;26:361-365.

19. Sdravou K, Walshe M, Dagdilelis L. Effects of Carbonated Liquids on Oropharyngeal Swallowing Measures in People with Neurogenic Dysphagia. Dysphagia. 2012;27:240-250.

20. Silva ACV, Dantas RO, Fabio SRC. Clinical and scintigraphic swallowing evaluation of post-strokepatients.Pró-Fono RAtual Cient.2010;22(3):317324

21. Silva ACV, Fabio SRC, Dantas RO. Scintigraphic Study of Oral, Pharyngeal, and Esophageal Transitin Patients with Stroke. Dysphagia. 2008;23:165-171.

22. Silva RG. A eficácia da reabilitação em disfagia orofaríngea. PróFono R Atual Cient. 2007;19(1):123-130.

23. Silva RG, Jorge AG, Peres FM, Cola PC, Gatto AR, Spadotto AA Protocolo para controle de eficácia terapêutica em disfagia orofaríngea neurogênica (PROCEDON). Rev CEFAC. 2010;12(1):75-81.

24. Sordi M, Mourão LF, Silva, LBC. Comportamento reológico e nomenclatura dos alimentos utilizados por fonoaudiólogos de serviços de disfagia. Rev CEFAC. 2011;14(5):925-932.

25. Sura L, Madhavan A, Carnaby G, Crary MA. Dysphagia in the elderly: management and nutritional considerations. Clin Interv Aging. 2012;7:287-298.

26. Taniguchi H, Tsukada T, OotakiS, Yamada Y, Inoue M. Correspondence between food consistency and suprahyoid muscle activity, tongue pressure, and bolus transit times during the oropharyngeal phase of swallowing. J Appl Physiol. 2008;105:791-799.

27. The Cochrane Collaboration [Internet]. Cochrane Handbook for Systematic Reviews of Intervention. [cited October 2013]; Available from: http://www.cochrane.org/training/cochrane-handbook

28. Yoshikawa M, Yoshida M, Nagasaki T, Tanimoto K, Tsuga K, Akagawa $Y$, et al. Aspects of Swallowing in Healthy Dentate Elderly Persons OlderThan 80 Years.J Gerontol Ser. A-Med. Sci. 2005;60A(4):506-509. 